\title{
Rевенсн автіске: Comparative economic analysis and farm profit of food grains and safed musli crop
}

\author{
S.K. RAJAK AND A. K. SARAWAGI
}

Article Chronicle :

SUMMARY : The cultivation of medicinal and food grain crops provides sustainable means of natural source of high value industrial raw material for pharmaceutical, agrichemical, food and cosmetic industries and opens up new possibilities for higher level of gains for farmer with a significant scope for progress in rural economy. Considering the importance of medicinal and food grain crop, the present research study is undertaken to assess the Economic of Production and farm profit of food grain and medicinal crop in Malwa Plateau of Madhya Pradesh. The investigation area confined to Malwa Plateau of Madhya Pradesh, the Indore and Dhar areas were selected purposively on the basis of maximum area covered in wheat, sorghum, gram, soybean and safed musli. Ten farmers were selected from each villages thus a total 120 growers were selected by random sampling method. For the collection of required data, survey method was adopted to conduct the inquiry by personal visits and interview schedule were used to collect all the relevant information from the respondents. The cost of production analysis revealed that it was lowest in case of sorghum (Rs. 369.33/qtls.) followed by wheat (Rs. 572.80) soybean (Rs. 918.3) and Gram (Rs. 973.9/qtls), respectively. For safed musli cost of production per quintal was Rs. 15424.8 which was quit high. Result revealed that on an average farm business income of safed musli of sample farmers was 1.13 lakh and family labour income was 1.08 lakhs these both measure of farm profit where quit high in comparison to selected traditional crop namely soyabean, sorghum, wheat and gram. The family labour income from soybean was only 5200 and from sorghum, it was 7260. The family labour income was more in case of wheat and gram which was about 17,000 . It is apparent that from wheat and gram the family labour income was higher than Kharif crop soybean and sorghum. The similar case was observed in the selected crop as regarded the cost benefit ratio it was higher, in case of gram 1:2.39 than other selected crops followed by wheat (1:2.10) it was lowest in case of safed musli (1:1.21).

How to cite this article : Rajak, S.K. and Sarawagi, A.K. (2017). Comparative economic analysis and farm profit of food grains and safed musli crop. Agric. Update, 12(TECHSEAR-6) : 1621-1624; DOI: 10.15740/HAS/AU/ 12. TECHSEAR(6)2017/1621-1624.

Author for correspondence :

\section{S.K. RAJAK}

College of Agriculture, Balaghat, J.N.K.V.V., JABALPUR (M.P.) India Email: sunildamoh @yahoo.com 